\title{
Cassava-Starch-Based Films Supplemented with Propolis Extract: Physical, Chemical, and Microstructure Characterization
}

\author{
Giana Ferreira Cunha ${ }^{1}\left(\mathbb{D}\right.$, Jackeline Cintra Soares ${ }^{2}{ }^{\mathbb{D}}$, Tainara Leal de Sousa ${ }^{3}{ }^{(\mathbb{D}}$, Mariana Buranelo \\ Egea $^{3, *(D)}$, Severino Matias de Alencar ${ }^{2}$ (D), Celso Martins Belisário ${ }^{3}$ (D) , Geovana Rocha Plácido ${ }^{3, *}$ (D) \\ 1 Instituto Federal de Educação, Ciência e Tecnologia Goiano, Campus Rio Verde, Rod. Sul Goiana, Km 01, 75.901-970 \\ Zona Rural, Rio Verde, GO, Brazil; e-mail: giana.fer@hotmail.com (G.F.C.), mariana.egea@ifgoiano.edu.br (M.B.E.), \\ celso.belisario@ifgoiano.edu.br (C.M.B.), geovana.placido@ifgoiano.edu.br (G.R.P.); \\ 2 Department of Agri-Food Industry, Food and Nutrition, "Luiz de Queiroz" College of Agriculture, University of São \\ Paulo, Pádua Dias Avenue, P.O. Box. 9, 13418-900, Piracicaba, SP, Brazil; e-mail: jackelinesoares@usp.br (J.C.S.), \\ smalencar@usp.br (S.M.d.A.); \\ 3 Goias Federal University (UFG), Institute of Tropical Pathology and Public Health, IPTSP - UFG, Street 235, s/n - East \\ University Sector, CEP 74605-450, Goiânia, GO, Brazil; thaynaraleal2@ hotmail.com (T.L.d.S.); \\ * Correspondence: mariana.egea@ifgoiano.edu.br (M.B.E);
}

Scopus Author ID 57189757361

Received: 2.12.2020; Revised: 29.12.2020; Accepted: 30.12.2020; Published: 2.01.2021

\begin{abstract}
Considering the current trends in the development of biodegradable films and materials interacting with food packaging through the incorporation of active substances into the packaging material, the possibility of using propolis as a natural bioactive compound was evaluated in order to propose a bioactive packaging development technology. Cassava-starch-based films were supplemented with propolis extract (PE) at concentrations of 0,30 , and $60 \mathrm{~g}$ per $100 \mathrm{~g}$ of starch. The chemical profile and antioxidant and antimicrobial activities of the PE were evaluated. The effect of PE incorporation on the film's mechanical properties and the microstructure, the concentration of phenolic compounds, and the antioxidant activity were also evaluated. Artepelin C $(10.957 \mathrm{mg} / \mathrm{mL})$ was the highest compound identified in PE. The $S$. aureus was more susceptible to PE than E. coli. The PE incorporation into the cassava starch-based films improved their flexibility and extensibility while making them more homogeneous and less harsh. Cassava starch-based films include phenolic compounds and antioxidant activity from PE. In the present work, the developed film revealed its potential as active food packaging materials, reducing the number of synthetic antioxidants used for food preservation.
\end{abstract}

Keywords: green propolis; bioactive compound; antioxidant activity; active packging antimicrobial properties.

(C) 2020 by the authors. This article is an open-access article distributed under the terms and conditions of the Creative Commons Attribution (CC BY) license (https://creativecommons.org/licenses/by/4.0/).

\section{Introduction}

Plastic films are used on large scales in food packaging because they can be produced in large quantities at low cost with good mechanical and barrier characteristics. However, the accumulation of synthetic plastics waste in the environment has driven the research into the development of biodegradable packaging as an environment-friendly strategy [1]. Moreover, biodegradable materials in plastics production only become viable if it is financially and functionally attractive compared to synthetic production routes. Agro-industrial raw materials can be used for the production of biofilms. The incorporation of bioactive compounds into the 
films, such as the propolis extract, allows the elaboration of films to offer extra benefits when compared to conventional materials [2-4].

The strategy to control phytopathogens' growth during post-harvest of fruits is the use of active edible coatings [5]. Edible coatings are defined as a thin layer produced from proteins, polysaccharides, and/or lipids that cover food surfaces that act as a protective layer [6]. The choice of the material to be used in the films' formulation is crucial. This will depend on the interactions between the components of the material, which may react with the films' barrier and mechanical properties. Starch has been considered an excellent raw material for the production of polymers due to its ability to form a continuous matrix, low oxygen permeability, cyclic availability, low cost, and harmless to the environment and rapidly metabolized for soil microorganisms when disposed of in the environment [7-10].

Due to the need to avoid oxidative deterioration of packaged food, the interest in active packaging has increased [11]. Besides the conservation of food, this type of system can present additional functionality to support antioxidant substances. Thus, incorporating antioxidant compounds into biodegradable films would promote new ways to improve the safety and shelflife of ready-to-eat foods $[4,12,13]$. A natural substance with a high potential to act as an additive in polymeric materials is the propolis extract [14-16].

Propolis, a natural resinous substance collected from plant resins by bees, has antibacterial, anti-fungal, anti-cancer, anti-inflammatory, antioxidant, antiviral, anesthetic, immunostimulant, and cytostatic effects [17-20]. Studies involving starch films with propolis extract (PE) as a source of bioactive compounds are still scarce in the literature. The present study's objective was to evaluate the antimicrobial activity against Escherichia coli and Staphylococcus aureus, the chemical profile, and the antioxidant activity of the Brazilian green propolis extract (PE), and the effect of supplementation of cassava starch-based films with PE.

\section{Materials and Methods}

\subsection{Materials.}

Caffeic acid (PubChem CID: 689043), p-coumaric acid (PubChem CID: 637542), 3,5Di-O-caffeoylquinic acid (PubChem CID: 13604687), 4,5-Di-O-caffeoylquinic acid (PubChem CID: 6474309), aromadendrin (PubChem CID: 122850), drupanin (PubChem CID: 6440361), artepillin C (PubChem CID: 5472440), and baccharin (PubChem CID: 5358645) were acquired from Sigma Aldrich (St. Loius, MO, US).

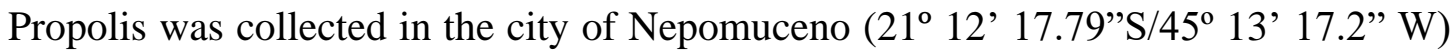
(Minas Gerais state, Brazil). Propolis extract (PE) was prepared, according to Bodini, Sobral, Favaro-Trindade, and Carvalho [14]. Briefly, a sample of $30 \mathrm{~g}$ of propolis was triturated with $100 \mathrm{~mL}$ of ethyl alcohol (80:20, etanol:water, v/v) under heating at $50{ }^{\circ} \mathrm{C}$ and stirring for 30 minutes. Then, the PE was then cooled, stored at $10{ }^{\circ} \mathrm{C}$ for 24 hours, and then filtered through a Whatman No. 4 filter paper.

\subsection{Characterization of propolis extract (PE).}

\subsubsection{Antimicrobial activity.}

The antimicrobial activity of the EEP was determined by the microdilution technique in 96-well microplates (NCCLS, 2003) against Escherichia coli (ATCC25922) and Staphylococcus aureus (ATCC25923). The initial microorganism suspensions were prepared 
in saline solution $(0.85 \%, \mathrm{w} / \mathrm{v})$ with a turbidity of $0.08-0.1$ at $625 \mathrm{~nm}$ measured using a spectrophotometer. The initial suspension was diluted in Mueller Hinton Broth to the concentration of $5 \times 10^{5} \mathrm{CFU} / \mathrm{mL}$. An aliquot of the suspension $(10 \mu \mathrm{L})$ was added to all wells with the PE (yielding a total of $5 \times 10^{3} \mathrm{CFU} / \mathrm{mL}$ ), and the plates were incubated at $36 \pm 1{ }^{\circ} \mathrm{C}$ for 24 hours for further evaluation of cell viability. Minimum inhibitory concentration (MIC) was defined as the lowest concentration of PE that shows no growth of microorganisms from an aliquot of the mixture $(10 \mu \mathrm{L})$ inoculated on Mueller Hinton Broth incubated at $36 \pm 1{ }^{\circ} \mathrm{C}$ for 24 hours, while minimum bactericidal concentration (MBC) was defined as the lowest concentration of $\mathrm{PE}$ that shows no growth of microorganisms from an aliquot of the mixture $(20 \mu \mathrm{L})$ inoculated on Mueller Hinton medium at $36 \pm 1{ }^{\circ} \mathrm{C}$ for 24 hours under anaerobic conditions.

\subsubsection{Phenolic composition of propolis extract.}

Chromatographic analysis of PE was performed using a High-Performance Liquid Chromatograph (HPLC) (Shimadzu LC-20AT Prominence Liquid Chromatograph) equipped with a diode array detector (HPLC-UV-DAD), automatic injector, oven, degasser, and quaternary pump. The Shim-Pack VP-ODS column $(4,6 \mathrm{~mm}$ x $250 \mathrm{~mm}$, a particle diameter of $5 \mu \mathrm{m})$ was used. The mobile phase consisted of a solution of methanol and $0.1 \%$ formic acid in water. Elution was performed using a linear gradient from 25 to $100 \%$ in 77 minutes at a flow rate of $0.8 \mathrm{~mL}$. The temperature was maintained at $40{ }^{\circ} \mathrm{C}$, and the injection volume was $10 \mu \mathrm{L}$. The spectral data were collected at $275 \mathrm{~nm}$, and identification was performed by comparison of retention times with those of standards. Patterns were used to quantify phenolic compounds using a calibration curve. The standards used were: gallic acid, caffeic acid, pcoumaric acid, aromadendrin, artepelin C, 3,5-dicafeoylquinic, 4,5-dicapheoquinquine, drupamine, and baccharin. The minimum detection limits were $0.12 \mu \mathrm{g} / \mathrm{mL}$ and $0.35 \mu \mathrm{g} / \mathrm{mL}$.

\subsection{Film development and characterization.}

The filmogenic solutions were obtained by mixing $3 \mathrm{~g}$ of cassava starch and $100 \mathrm{~mL}$ of distilled water described by López et al. [21]. After the suspension was wholly dissolved, glycerol $\left(20 \mathrm{~g} / 100 \mathrm{~g}\right.$ of starch) was added, and the solution was heated at $70{ }^{\circ} \mathrm{C}$ and then cooled to $40^{\circ} \mathrm{C}$. Finally, PE in three concentrations $(0,30$, and $60 \mathrm{~g} / 100 \mathrm{~g}$ of starch) and ethyl alcohol (15 g/100 g of starch) were added to the mixture. The film solution was kept in an ultrasonic bath for 20 minutes to avoid bubble formation. $100 \mathrm{~mL}$ of the film-forming were then spread on each petri dish $\left(15 \times 15 \mathrm{~cm}^{2}\right)$ and dried in BOD chamber at $40{ }^{\circ} \mathrm{C}$ for 30 hours.

\subsubsection{Film characterization.}

The films were equilibrated at $23 \pm 2{ }^{\circ} \mathrm{C}$ and $50 \% \pm 10$ relative humidity with a desiccator over 48 hours. The thickness of the films was determined using a digital micrometer $(n=10)[22]$.

\subsubsection{Mechanical properties.}

The tensile strength, elongation at rupture, and Young's modulus were determined using a texture analyzer (Instron - Series 3367, Grove City, US) [23] ( $\mathrm{n}=10)$. The films were cut into a piece of $10 \mathrm{~cm} \times 1.5 \mathrm{~cm}$ and conditioned at $50 \pm 10 \% \mathrm{RH}$ at $23{ }^{\circ} \mathrm{C} \pm 2$ for 48 hours. A $500 \mathrm{~N}$ load cell was used, and the tensile force was recorded during the extension of films to 
$0.2 \mathrm{~mm} / \mathrm{s}$ until rupture. The tensile strength values, elongation at rupture, and Young's modulus were estimated from force deformation data.

\subsubsection{Morphological properties.}

Scanning electron microscopy analysis of the films was performed using an electron microscope. JSM-6610 series scanning electron microscope (Jeol@, Tokyo, Japão) equipped with EDS at $5 \mathrm{kV}$ accelerating voltage. The films were placed on conductive carbon tape and sprayed with a thin layer of gold before the imaging.

\subsection{Total phenolic content and antioxidant activity.}

Total phenolic content and antioxidant activity of PE and films were realized. The extract from films was performed using a mixture of $11 \mathrm{mg}$ and $6 \mathrm{~mL}$ of water heated to $50{ }^{\circ} \mathrm{C}$ for 50 minutes. $4 \mathrm{~mL}$ of ethyl alcohol $(80 \%)$ was added, and the temperature was maintained for another 10 minutes with subsequent filtration.

Total phenolic content was realized as described by Al-Duais et al. [24] with adapted for micro volumes. Briefly, $20 \mu \mathrm{L}$ of the extracts were mixed with $100 \mu \mathrm{L}$ of the FolinCiocalteau reagent (10\%), and after 5 minutes, $75 \mu \mathrm{L}$ of $4 \%$ sodium carbonate $(7.5 \%)$ was added. After 40 minutes of the reaction, the absorbance was measured at $740 \mathrm{~nm}$ using a microplate reader Spectra-Max M3 (Molecular Devices, LLC, Sunnyvale, CA, US). The total content of phenolic compounds was expressed in gallic acid equivalent (GAE) calculated using a calibration curve (20 to $120 \mu \mathrm{g} / \mathrm{mL}$ ).

The antioxidant activity was determined using the $\mathrm{ABTS}^{\cdot+}$ scavenging method $\left(2,2^{\prime}-\right.$ azinobis (3-ethyl-benzothiazoline-6-sulfonic acid)) as described by Al-Duais, Müller, Böhm, and Jetschke [24]. $220 \mu \mathrm{L}$ of the ABTS $^{\circ+}$ solution and $20 \mu \mathrm{L}$ of Trolox or sample were mixed inside of each well of the microplate. Then, the plate was shaken and kept in the dark for 6 minutes. Absorption was measured at $734 \mathrm{~nm}$ using a microplate reader. The results are expressed in $\mu \mathrm{mol}$ Trolox equivalents calculated using a standard curve (12.5 to $200 \mu \mathrm{M})$.

\subsection{Statistical analyses.}

All tests were performed in triplicates with three replicates. Mechanical properties and thickness were carried out in ten replicates were run for each sample. Data are expressed as mean \pm standard deviation, and statistical comparison between groups was carried out using analysis of variance (ANOVA) followed by Tukey's test $(\mathrm{p}<0.05)$.

\section{Results and Discussion}

\subsection{Propolis extract characterization.}

Table 1 shows the minimum inhibitory concentration (MIC) and minimum bactericidal concentration (MBC) of propolis extract. Although the PE showed activity against the two microorganisms tested, S. aureus was more susceptible to PE than E. coli.

Table 1. Minimum inhibitory concentration (MIC) and minimum bactericidal concentration (MBC) of propolis extract $(n=3)$.

\begin{tabular}{c|c|c|c}
\multicolumn{2}{c|}{ Microorganisms } & MIC $(\mathbf{m g} / \mathbf{m L})$ & MBC $(\mathbf{m g} / \mathbf{m L})$ \\
\hline S. aureus (ATCC25923) & Gram-positive & $0.017 \pm 0.00$ & $0.161 \pm 0.00$ \\
\hline E. coli (ATCC25922) & Gram-negative & $0.161 \pm 0.00$ & $1.288 \pm 0.00$
\end{tabular}


These results corroborate what has been described in the literature [25,26], demonstrating propolis is more active against gram-positive than gram-negative bacteria $[27,28]$. Gram-negative bacteria have a chemically complex cell membrane. One of its constituents, the lipopolysaccharide, determines the antigenicity, toxicity, and pathogenicity of these microorganisms $[29,30]$. The bactericidal and bacteriostatic effects of propolis can result from the combined actions of cinnamic and flavonoid derivatives, increasing the permeability of the bacterial cell membrane by acting as ionophores, inhibiting the motility, and thereby contributing to the cytotoxic effect [28,31].

Figure 1 and Table 2 show the HPLC analysis of PE. The phenolic compounds identified were: caffeic acid, p-coumaric acid, 3,5-di-O-caffeoylquinic acid, 4,5-Di-Ocaffeoylquinic acid, aromadendrin, drupanin, artepelin $\mathrm{C}$, baccharin, and levels of prenylated phenolic acids, including artepelin $\mathrm{C}$.

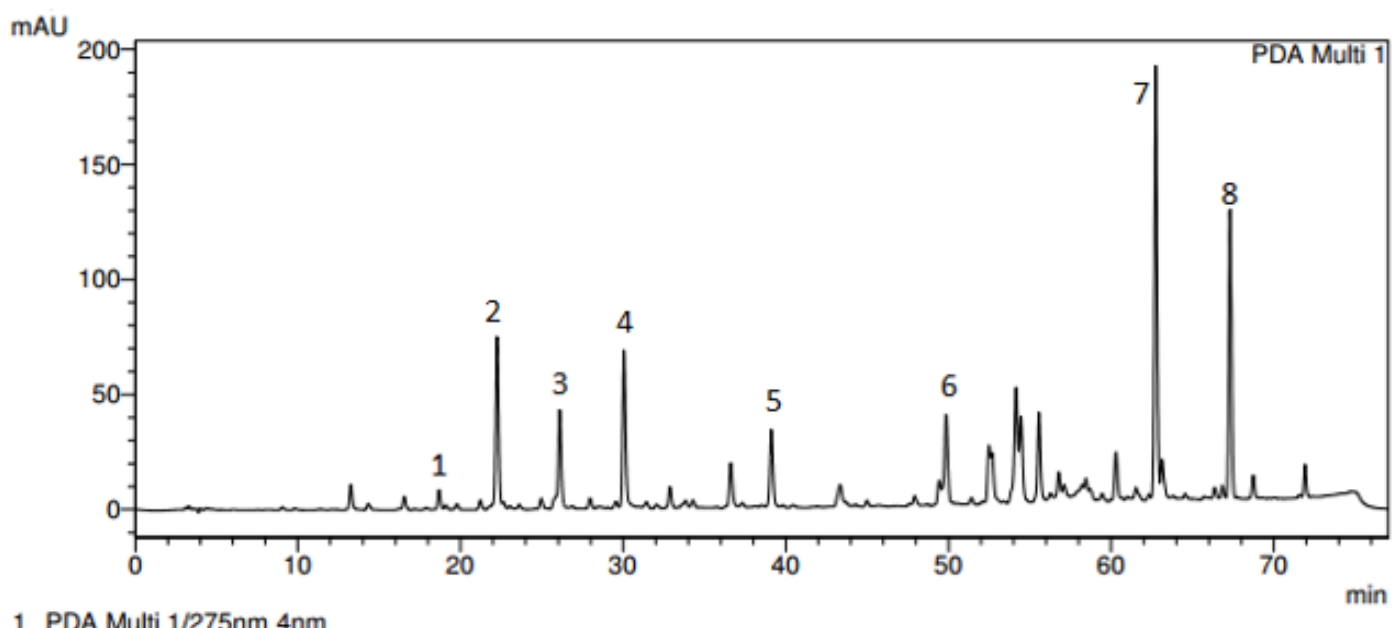

Figure 1. High-performance liquid chromatography (HPLC) of propolis extract detected at $2754 \mathrm{~nm}$.

Table 2. Phenolic compounds of propolis extract determined using High-Performance Liquid Chromatography with Diode Array Detector (HPLC-DAD).

\begin{tabular}{c|c|c|c} 
Peak Number & Phenolic compound & Retention time $(\mathbf{m i n})$ & $\mathbf{m g} / \mathbf{m L}$ of PE \\
\hline 1 & Caffeic acid & 19 & 0.278 \\
\hline 2 & p-coumaric acid & 23 & 1.494 \\
\hline 3 & 3,5-dinitrocatechol & 26 & 2.975 \\
\hline 4 & 4,5-di-caffeoylquinic acid & 30 & 4.761 \\
\hline 5 & Aromadendrin & 39 & 1.623 \\
\hline 6 & Drupanin & 50 & 2.017 \\
\hline 7 & Artepillin C & 63 & 10.957 \\
\hline 8 & Baccharin & 67 & 2.263
\end{tabular}

The main compound found in the present work was artepillin C $(10.96 \mathrm{mg} / \mathrm{mL})$, which had already been reported in the literature. The compound was present in greater quantity in Brazilian green propolis [32,33]. This is one of the most important biologically active compounds in Brazilian green propolis [34], previously reported for important biological activities including antitumor [35,36], immunomodulatory, and immunosuppressive effects [37], as well as induction of apoptosis and excellent scavenging of free radicals $[38,39]$.

\subsection{Characteristics of the cassava-based film supplemented with propolis extract.}

\subsubsection{Physical and morphologic characteristics.}

Table 3 shows the thickness measurements and mechanical characteristics of the cassava-based films with propolis extract. There was no difference in the thickness after PE addition, indicating that the propolis extract did not alter the solids in the filmogenic solutions. 
Table 3. Physical and morphologic characteristics of cassava-based film supplemented with propolis extract in the concentration of 0 (PE0), 30 (PE30), and 60 (PE60) g per100 $\mathrm{g}$ of starch.

\begin{tabular}{c|c|c|c|c} 
Films & Thickness $(\mathbf{m m})$ & Tensile strength (MPa) & Elongation at rupture (\%) & Young's modulus (MPa) \\
\hline PE0 & $0.07 \pm 0.00^{\mathrm{a}}$ & $13.66 \pm 0.06^{\mathrm{a}}$ & $1.61 \pm 0.03^{\mathrm{c}}$ & $1196.21 \pm 52.71^{\mathrm{a}}$ \\
\hline PE30 & $0.07 \pm 0.00^{\mathrm{a}}$ & $6.47 \pm 0.72^{\mathrm{b}}$ & $20.58 \pm 2.21^{\mathrm{b}}$ & $471.94 \pm 54.19^{\mathrm{b}}$ \\
\hline PE60 & $0.07 \pm 0.00^{\mathrm{a}}$ & $4.55 \pm 0.33^{\mathrm{b}}$ & $28.39 \pm 1.32^{\mathrm{a}}$ & $277.41 \pm 7.41^{\mathrm{c}}$
\end{tabular}

Different letters in the same column indicate a significant difference by the Tukey test $(\mathrm{p}>0.05)$.

When tensile strength and Young's modulus decreased with the addition of PE (concentration-dependent), elongation at rupture increased with the addition of PE. This increase in elongation at rupture resulted in more flexible films. We hypothesized that PE might have acted with plasticizing behavior due to its strong interaction with the starch's polymer matrix. The polar compounds of the PE may form molecular interactions with the hydroxyl groups, substituting the interactions previously formed by the starch molecules. This plasticizing effect of PE was related to biodegradable gelatin films with PE (5 to $200 \mathrm{~g}$ of $\mathrm{PE} / 100 \mathrm{~g}$ of gelatin), resulting reduction in tensile strength and modulus of elasticity with an increase of PE concentration [14]. For applications such as packaging, tray coverings in food storage, or the like, the films developed in the present work can confer an advantage due to their high elongation capacity.

Figure 2 shows the surface micrographs of cassava-based film supplemented with propolis extract. The films' surface micrographs revealed the presence of insoluble particles in all treatments, characterized by residual starch dispersed in the film matrix. This indicates an incomplete dissolution of the starch molecules during the process. However, the amount of non-solubilized starch granules decreased on the surface of the films supplemented with PE.

The PE addition to the polymer matrix granted greater homogeneity to the films due to hydroxyl groups on the phenolic compounds present in PE. These hydroxyl groups form hydrogen bonds with hydroxyl groups of starch and, consequently, reduce the intermolecular interactions between the polymer chains, improving the film's homogeneity [40]. The PE concentration increase also made the film less harsh, reflecting the compounds present in the PE with the cassava starch.
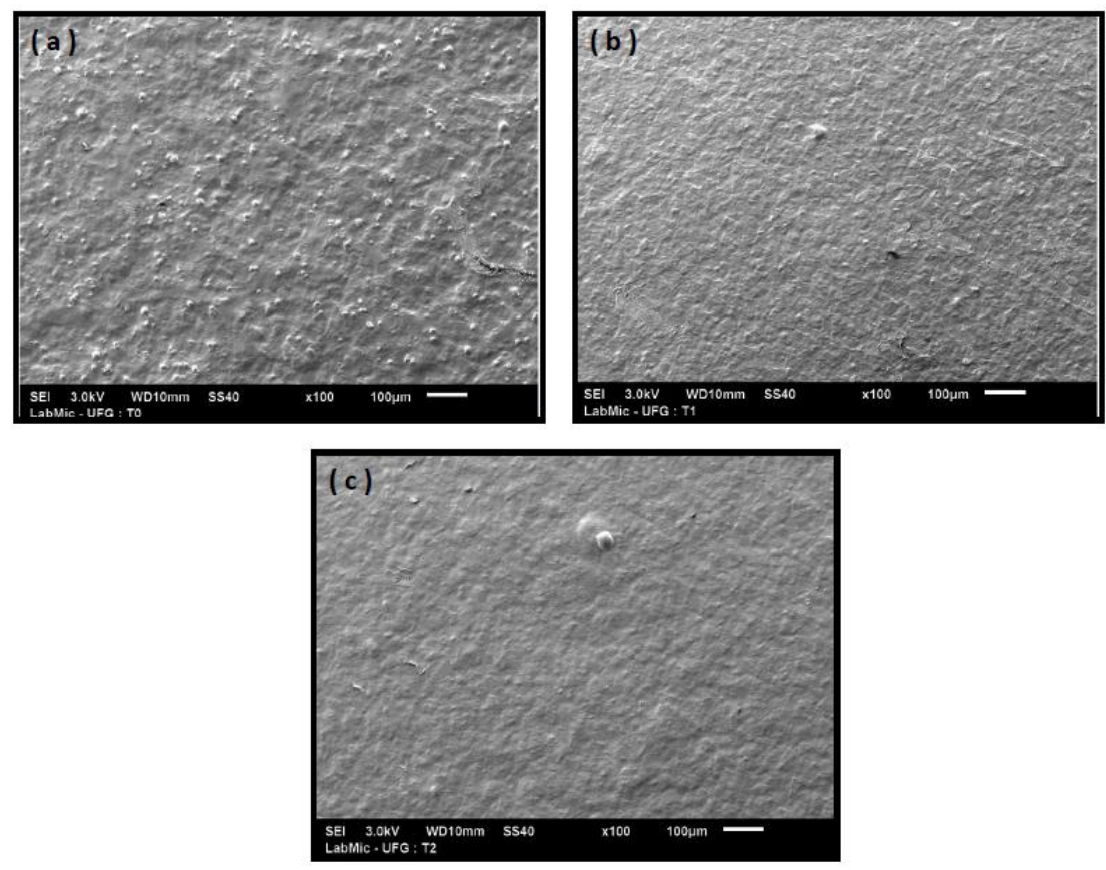

Figure 2. Surface image $(100 \mathrm{x})$ cassava-based film supplemented with propolis extract: (a) PE0: film without propolis extract, (b) PE30: film with $30 \mathrm{~g}$ of propolis extract per $100 \mathrm{~g}$ of starch, and (c) PE60: film with $60 \mathrm{~g}$ of propolis extract per $100 \mathrm{~g}$ of starch. 
In the present work, the film of matrix homogeneity results in diminishing the films' mechanical resistance, which was previously related by other authors [2,3]. Moreover, the films' maximum tensile strength decreased with the addition of PE and presented a significant difference in relation to the control (Table 3).

3.2.2. Total phenolic content (TPC) and antioxidant activity of cassava-based film supplemented with propolis extract.

Table 4 shows TPC and antioxidant activity of developed films. The propolis extract presented a TPC of $\sim 39 \mathrm{mg} \mathrm{GAE} / \mathrm{g}$, close to that reported by da Silva et al. [41] for the propolis from Minas Gerais state (4.10 to $39.0 \mathrm{mg} \mathrm{GAE} / \mathrm{mL}$ ). The main components of propolis from São Paulo and Minas Gerais states are terpenoids and prenylated derivatives of p-coumaric acid [25], which also were found in the present study (Table 2).

Table 4. Total phenolic compounds and antioxidant activity of cassava-based film supplemented with propolis extract (PE) in the concentration of 0 (PE0), 30 (PE30), and 60 (PE60) g per100 $\mathrm{g}$ of starch.

\begin{tabular}{c|c|c|c} 
Samples & Total phenolic compounds $(\mathbf{m g ~ G A E} / \mathbf{g})$ & $\mathbf{A B T S}^{\bullet+}(\boldsymbol{\mu m o l ~ T E} / \mathbf{g})$ & $\mathbf{A B T S}^{\bullet+}(\mathbf{m g} \mathbf{T E} / \mathbf{g})$ \\
\hline PE & $38.40 \pm 0.36^{\mathrm{a}}$ & $845.21 \pm 6.99^{\mathrm{a}}$ & $211.35 \pm 0.4^{\mathrm{a}}$ \\
\hline PE0 & $0^{\mathrm{d}}$ & $0^{\mathrm{c}}$ & $0^{\mathrm{c}}$ \\
\hline PE30 & $4.18 \pm 0.28^{\mathrm{c}}$ & $38.18 \pm 1.33^{\mathrm{b}}$ & $9.55 \pm 0.13^{\mathrm{b}}$ \\
\hline PE60 & $5.52 \pm 0.21^{\mathrm{b}}$ & $38.62 \pm 0.69^{\mathrm{b}}$ & $9.66 \pm 0.60^{\mathrm{b}}$
\end{tabular}

GAE: gallic acid equivalent; TE = Trolox equivalent. Different letters in the same column indicate a significant difference by the Tukey test $(\mathrm{p}>0.05)$.

In the present work, propolis extract showed antioxidant activity close to propolis from Minas Gerais region (77.90 to $86.40 \mathrm{mg}$ TE/mL using the ABTS method) [42] and propolis samples from the southern region of Brazil ( 0.29 to $1.24 \mu \mathrm{mol} \mathrm{TE} / \mathrm{mg}$ using the ABTS method) [43]. Tiveron et al. [43] showed the high antioxidant activity of artepelin $\mathrm{C}$ when compared to other compounds such as caffeic acid, coumaric acid, and gallic acid also present in propolis extract. The highest concentrations of artepelin $\mathrm{C}$ already observed in natural products are those from the green propolis produced in the South and Southeast of Brazil, whose source is the plant species Baccharis dracunculifolia [44].

Although artepelin $\mathrm{C}$ is one of the main compounds responsible for the antioxidant activity, the compounds verified in the HPLC analysis such as caffeic acid and derivatives, aromadendrin, and baccharin also have proven antioxidant activities and therefore may also have been responsible for the antioxidant activity of the extract [45]. Although the total concentration of phenolic compounds or flavonoids is important for contributing to antioxidant activity, the chemical nature (molecule structure, presence, and nature of groups linked to the main molecule) and the presence of other compounds may also contribute total antioxidant activity of the sample as well [42].

The propolis extract contributed to the increase in TPC (dose-dependent) (4.18-5.52 $\mathrm{mg}$ GAE/g) and antioxidant activity (38.18-38.62 $\mu \mathrm{mol} \mathrm{TE} / \mathrm{g})$ of cassava-based films. Our results are in the same range found by Zhao and Saldaña [46]. These authors produced films with potato by-products and demonstrated that when the potato peel concentration in the film is increased, the total phenolic content (0.3-6.1 mg GAE/g of the film) and antioxidant activity of the films (1.5-93.2 mg TE/g film using the ABTS method) is also increased. However, when gallic acid was added to the films, the film showed higher antioxidant activity $(1.5-1974.0 \mathrm{mg}$ $\mathrm{TE} / \mathrm{g}$ of film using the ABTS method). Our results are in the same range found by these authors. 
Due to the antioxidant properties found in cassava starch films supplemented with PE, it is expected that film to assist in the inhibition of lipid oxidation can occur in several types of foods and thereby help decrease the number of synthetic antioxidants used in food preservation.

\section{Conclusions}

The ethanolic extract of green propolis presented great potential for use as a bioactive compound with antioxidant properties in developing active packaging produced from cassava starch. The incorporation of the propolis extract into the starch biofilms resulted in homogeneous films, reflect on the compatibility of the compounds present in the propolis extract with the cassava starch. The films showed a decrease in mechanical strength and improved flexibility and extensibility, which can be appreciated by the packaging industry. Finally, according to the intended usage, the amount of propolis extract can be adjusted in complementary studies.

\section{Funding}

This research received no external funding.

\section{Acknowledgments}

The authors are grateful for the support and partnership of the Company ELEVE Research and Development (Apis Flora) and the Goiano Federal Institute - Rio Verde Campus.

\section{Conflicts of Interest}

The authors declare no conflict of interest.

\section{References}

1. Kiygi-Calli, M. Corporate Social Responsibility in Packaging: Environmental and Social Issues. In: Ethics, Social Responsibility and Sustainability in Marketing. Springer: 2019; pp. 129-144, https://doi.org/10.1007/978-981-13-7924-6_7.

2. Maniglia, B.; Tessaro, L.; Lucas, A.; Tapia-Blácido, D. Bioactive films based on babassu mesocarp flour and starch. Food Hydrocolloids 2017, 70, 383-391, https://doi.org/10.1016/j.foodhyd.2017.04.022.

3. Moreno, O.; Gil, A.; Atarés, L.; Chiralt, A. Active starch-gelatin films for shelf-life extension of marinated salmon. LWT 2017, 84, 189-195, https://doi.org/10.1016/j.lwt.2017.05.005.

4. Oliveira Filho, J.; Lemes, A.; Braga, A.; Egea, M. Biodegradable Eco-Friendly Packaging and Coatings Incorporated of Natural Active Compounds. In: Food Packaging: Advanced Materials, Technologies, and Innovations. Oliviera-Filho, J.G.; Lemes, A.C.; Nraga, A.R.C.; Egea, M.B. Ed. CRC Press: Boca Raton, 2020; pp. 171-205.

5. Moreno, M.; Vallejo, A.; Ballester, A.-R.; Zampini, C.; Isla, M.; López-Rubio, A.; Fabra, M. Antifungal edible coatings containing Argentinian propolis extract and their application in raspberries. Food Hydrocolloids 2020, 107, https://doi.org/10.1016/j.foodhyd.2020.105973.

6. Grosso, A.; Asensio, C.; Grosso, N.; Nepote, V. Increase of walnuts' shelf life using a walnut flour proteinbased edible coating. LWT 2020, 118, https://doi.org/10.1016/j.lwt.2019.108712.

7. Mukurumbira, A.; Mellem, J.; Amonsou, E. Effects of amadumbe starch nanocrystals on the physicochemical properties of starch biocomposite films. Carbohydrate polymers 2017, 165, 142-148, https://doi.org/10.1016/j.carbpol.2017.02.041.

8. Colussi, R.; Pinto, V.; El Halal, S.; Biduski, B.; Prietto, L.; Castilhos, D.; da Rosa Zavareze, E.; Dias, A. Acetylated rice starches films with different levels of amylose: Mechanical, water vapor barrier, thermal, and biodegradability properties. Food chemistry 2017, 221, 1614-1620, https://doi.org/10.1016/j.foodchem.2016.10.129.

9. Jiang, G.; Hou, X.; Zeng, X.; Zhang, C.; Wu, H.; Shen, G.; Li, S.; Luo, Q.; Li, M.; Liu, X. Preparation and characterization of indicator films from carboxymethyl-cellulose/starch and purple sweet potato (Ipomoea 
batatas (L.) lam) anthocyanins for monitoring fish freshness. International Journal of Biological Macromolecules 2020, 143, 359-372, https://doi.org/10.1016/j.ijbiomac.2019.12.024.

10. Dai, L.; Zhang, J.; Cheng, F. Cross-linked starch-based edible coating reinforced by starch nanocrystals and its preservation effect on graded Huangguan pears. Food Chemistry 2020, 311, https://doi.org/10.1016/j.foodchem.2019.125891.

11. Dobrucka, R.; Przekop, R. New perspectives in active and intelligent food packaging. Journal of Food Processing and Preservation 2019, 43, https://doi.org/10.1111/jfpp.14194.

12. Motelica, L.; Ficai, D.; Ficai, A.; Oprea, O.; Kaya, D.A.; Andronescu, E. Biodegradable antimicrobial food packaging: Trends and perspectives. Foods 2020, 9, https://doi.org/10.3390/foods9101438.

13. Suhag, R.; Kumar, N.; Petkoska, A.; Upadhyay, A. Film formation and deposition methods of edible coating on food products: A review. Food Research International 2020, 136, https://doi.org/10.1016/j.foodres.2020.109582.

14. Bodini, R.; Sobral, P.d.A.; Favaro-Trindade, C.; Carvalho, R.D. Properties of gelatin-based films with added ethanol-propolis extract. LWT-Food Science and Technology 2013, 51, 104-110, https://doi.org/10.1016/j.lwt.2012.10.013.

15. Dallabona, I.; de Lima, G.; Cestaro, B.; de Souza Tasso, I.; Paiva, T.S.; Laureanti, E.; de Matos Jorge, L.; da Silva, B.; Helm, C.; Mathias, A. Development of alginate beads with encapsulated jabuticaba peel and propolis extracts to achieve a new natural colorant antioxidant additive. International Journal of Biological Macromolecules 2020, 163, 1421-1432, https://doi.org/10.1016/j.ijbiomac.2020.07.256.

16. Mustafa, P.; Niazi, M.; Jahan, Z.; Samin, G.; Hussain, A.; Ahmed, T.; Naqvi, S. PVA/starch/propolis/anthocyanins rosemary extract composite films as active and intelligent food packaging materials. Journal of Food Safety 2020, 40, https://doi.org/10.1111/jfs.12725.

17. Zabaiou, N.; Fouache, A.; Trousson, A.; Baron, S.; Zellagui, A.; Lahouel, M.; Lobaccaro, J.-M. Biological properties of propolis extracts: Something new from an ancient product. Chemistry and physics of lipids 2017, 207, 214-222, https://doi.org/10.1016/j.chemphyslip.2017.04.005.

18. Yonar, M.; Yonar, S.; Silici, S. Protective effect of propolis against oxidative stress and immunosuppression induced by oxytetracycline in rainbow trout (Oncorhynchus mykiss, W.). Fish \& shellfish immunology 2011, 31, 318-325, https://doi.org/10.1016/j.fsi.2011.05.019.

19. Anjum, S.; Ullah, A.; Khan, K.; Attaullah, M.; Khan, H.; Ali, H.; Bashir, M.; Tahir, M.; Ansari, M.; Ghramh, H. Composition and functional properties of propolis (bee glue): A review. Saudi Journal of Biological Sciences 2019, 26, 1695-1703, https://doi.org/10.1016/j.sjbs.2018.08.013.

20. Kechichian, V.; Ditchfield, C.; Veiga-Santos, P.; Tadini, C. Natural antimicrobial ingredients incorporated in biodegradable films based on cassava starch. LWT-Food Science and Technology 2010, 43, 1088-1094, https://doi.org/10.1016/j.lwt.2010.02.014.

21. López, O.; Lecot, C.; Zaritzky, N.; García, M. Biodegradable packages development from starch based heat sealable films. Journal of Food Engineering 2011, 105, 254-263, https://doi.org/10.1016/j.jfoodeng.2011.02.029.

22. Oliveira Filho, J.; Bezerra, C.; Albiero, B.; Oldoni, F.; Miranda, M.; Egea, M.; Azeredo, H.; Ferreira, M. New approach in the development of edible films: the use of carnauba wax micro- or nanoemulsions in arrowroot starch-based films. Food Packaging and Shelf Life 2020, 26, https://doi.org/10.1016/j.fpsl.2020.100589.

23. D882-12, A. Standard Test Method for Tensile Properties of Thin Plastic Sheeting. ASTM International: West Conshohocken, 2012.

24. Al-Duais, M.; Müller, L.; Böhm, V.; Jetschke, G. Antioxidant capacity and total phenolics of Cyphostemma digitatum before and after processing: use of different assays. European Food Research and Technology 2009, 228, 813-821, https://doi.org/10.1007/s00217-008-0994-8.

25. Sforcin, J.; Fernandes Jr, A.; Lopes, C.; Bankova, V.; Funari, S. Seasonal effect on Brazilian propolis antibacterial activity. Journal of Ethnopharmacology 2000, 73, 243-249, https://doi.org/10.1016/S03788741(00)00320-2.

26. Silici, S.; Kutluca, S. Chemical composition and antibacterial activity of propolis collected by three different races of honeybees in the same region. Journal of ethnopharmacology 2005, 99, 69-73, https://doi.org/10.1016/j.jep.2005.01.046.

27. Przybyłek, I.; Karpiński, T. Antibacterial properties of propolis. Molecules 2019, 24, https://doi.org/10.3390/molecules24112047.

28. Lavigne, J.-P.; Ranfaing, J.; Dunyach-Rémy, C.; Sotto, A. Synergistic Effect of Propolis and Antibiotics on Uropathogenic Escherichia coli. Antibiotics 2020, 9, https://doi.org/10.3390/antibiotics9110739.

29. Nori, M.; Favaro-Trindade, C.; de Alencar, S.; Thomazini, M.; de Camargo Balieiro, J.; Castillo, C. Microencapsulation of propolis extract by complex coacervation. LWT-Food Science and Technology 2011, 44, 429-435, https://doi.org/10.1016/j.lwt.2010.09.010.

30. Breijyeh, Z.; Jubeh, B.; Karaman, R. Resistance of Gram-negative bacteria to current antibacterial agents and approaches to resolve it. Molecules 2020, 25, https://doi.org/10.3390/molecules25061340. 
31. Mirzoeva, O.; Grishanin, R.; Calder, P. Antimicrobial action of propolis and some of its components: the effects on growth, membrane potential and motility of bacteria. Microbiological research 1997, 152, 239246, https://doi.org/10.1016/S0944-5013(97)80034-1.

32. Beserra, F.; Gushiken, L.; Hussni, M.; Ribeiro, V.; Bonamin, F.; Jackson, C.; Pellizzon, C.; Bastos, J. Artepillin $\mathrm{C}$ as an outstanding phenolic compound of Brazilian green propolis for disease treatment: A review on pharmacological aspects. Phytotherapy Research 2020, https://doi.org/10.1002/ptr.6875.

33. Zhang, C.-P.; Shen, X.-G.; Chen, J.-W.; Jiang, X.-S.; Wang, K.; Hu, F.-L. Artepillin C, is it a good marker for quality control of Brazilian green propolis? Natural product research 2017, 31, 2441-2444, https://doi.org/10.1080/14786419.2017.1303697.

34. Shahinozzaman, M.; Basak, B.; Emran, R.; Rozario, P.; Obanda, D. Artepillin C: A comprehensive review of its chemistry, bioavailability, and pharmacological properties. Fitoterapia 2020, 147, https://doi.org/10.1016/j.fitote.2020.104775.

35. Bhargava, P.; Grover, A.; Nigam, N.; Kaul, A.; Ishida, Y.; Kakuta, H.; Kaul, S.; Terao, K.; Wadhwa, R. Anticancer activity of the supercritical extract of Brazilian green propolis and its active component, artepillin C: Bioinformatics and experimental analyses of its mechanisms of action. International journal of oncology 2018, 52, 925-932, https://doi.org/10.3892/ijo.2018.4249.

36. Sepúlveda, C.; Núñez, O.; Torres, A.; Guzmán, L.; Wehinger, S. Antitumor Activity of Propolis: Recent Advances in Cellular Perspectives, Animal Models and Possible Applications. Food Reviews International 2020, 36, 429-455, https://doi.org/10.1080/87559129.2019.1649692.

37. Wolska, K.; Gorska, A.; Antosik, K.; Lugowska, K. Immunomodulatory effects of Propolis and its components on basic immune cell functions. Indian Journal of Pharmaceutical Sciences 2019, 81, 575-588.

38. Veiga, R.; De Mendonça, S.; Mendes, P.; Paulino, N.; Mimica, M.; Lagareiro Netto, A.; Lira, I.; López, B.C.; Negrão, V.; Marcucci, M. Artepillin C and phenolic compounds responsible for antimicrobial and antioxidant activity of green propolis and Baccharis dracunculifolia DC. Journal of Applied Microbiology 2017, 122, 911-920, https://doi.org/10.1111/jam.13400.

39. Seibert, J.; Bautista-Silva, J.; Amparo, T.; Petit, A.; Pervier, P.; dos Santos Almeida, J.; Azevedo, M.; Silveira, B.; Brandão, G.; de Souza, G. Development of propolis nanoemulsion with antioxidant and antimicrobial activity for use as a potential natural preservative. Food chemistry 2019, 287, 61-67, https://doi.org/10.1016/j.foodchem.2019.02.078.

40. Zhai, X.; Shi, J.; Zou, X.; Wang, S.; Jiang, C.; Zhang, J.; Huang, X.; Zhang, W.; Holmes, M. Novel colorimetric films based on starch/polyvinyl alcohol incorporated with roselle anthocyanins for fish freshness monitoring. Food Hydrocolloids https://doi.org/10.1016/j.foodhyd.2017.02.014.

41. da Silva, J.; de Souza, M.; Matta, S.; de Andrade, M.; Vidal, F. Correlation analysis between phenolic levels of Brazilian propolis extracts and their antimicrobial and antioxidant activities. Food Chemistry 2006, 99 , 431-435, https://doi.org/10.1016/j.foodchem.2005.07.055.

42. Machado, B.; Silva, R.; Barreto, G.; Costa, S.; Silva, D.; Brandao, H.; Rocha, J.; Dellagostin, O.; Henriques, J.; Umsza-Guez, M. Chemical composition and biological activity of extracts obtained by supercritical extraction and ethanolic extraction of brown, green and red propolis derived from different geographic regions in Brazil. PloS one 2016, 11, https://doi.org/10.1371/journal.pone.0145954.

43. Tiveron, A.; Rosalen, P.; Franchin, M.; Lacerda, R.; Bueno-Silva, B.; Benso, B.; Denny, C.; Ikegaki, M.; Alencar, S. Chemical characterization and antioxidant, antimicrobial, and anti-inflammatory activities of South Brazilian organic propolis. PLoS One 2016, 11, https://doi.org/10.1371/journal.pone.0165588.

44. Rodrigues, C.; Plentz, L.; do Amaral Flores, M.; Dihl, R.; Lehmann, M. Assessment of genotoxic and antigenotoxic activities of artepillin $\mathrm{C}$ in somatic cells of Drosophila melanogaster. Food and Chemical Toxicology 2017, 101, 48-54, https://doi.org/10.1016/j.fct.2017.01.005.

45. Costa, P.; Almeida, M.; Lemos, M.; Arruda, C.; Casoti, R.; Somensi, L.; Boeing, T.; Mariott, M.; Stein, B.d.P.; de Souza, P. Artepillin C, drupanin, aromadendrin-4'-O-methyl-ether and kaempferide from Brazilian green propolis promote gastroprotective action by diversified mode of action. Journal of ethnopharmacology 2018, 226, 82-89, https://doi.org/10.1016/j.jep.2018.08.006.

46. Zhao, Y.; Saldaña, M. Use of potato by-products and gallic acid for development of bioactive film packaging by subcritical water technology. The Journal of Supercritical Fluids 2019, 143, 97-106, https://doi.org/10.1016/j.supflu.2018.07.025. 